\title{
The Influence of Water Content Variations on Friction Capacity of Piles in Expansive Soil
}

\author{
Daniel Tjandra ${ }^{1,2}$ Indarto $^{3}$ and Ria Asih Aryani Soemitro ${ }^{4}$ \\ ${ }^{1,3,4}$ Sepuluh Nopember Institute of Technology (ITS), Surabaya, Indonesia \\ ${ }^{2}$ Petra Christian University, Surabaya, Indonesia \\ ${ }^{1}$ danieltj@petra.ac.id, ${ }^{3}$ indarto1992@gmail.com, ${ }^{4}$ ria@ce.its.ac.id
}

\begin{abstract}
Seasonal change in tropical climate countries like Indonesia causes variations in soil moisture content. On expansive soil, this condition influences the soil moisture content in the upper few meters, which is generally termed as the active zone. The water content variation induces the changes in physical and mechanical characteristics of the soil and these changes have an impact to the friction capacity of piles. The main objectives of this research are to investigate the influence of water content variations on friction capacity of concrete and steel piles. A series of laboratory experiments were conducted considering the water content variations and pile material. A pile model made of concrete and steel was penetrated to soil sample which was placed in a cylindrical tube. This tube has a diameter about 15 times the diameter of the pile model. The pile model was loaded to failure to investigate the friction capacity. Based on the results from laboratory testing, it can be concluded that the change of water content have a great impact to friction capacity of piles. Friction capacity of concrete and steel piles has decreased up to eight and nine times from drying condition to wetting condition. The results also showed that pile material influenced the friction capacity which steel pile had higher friction capacity than concrete pile.
\end{abstract}

Keywords: Pile foundation, Friction capacity, Water content

\section{Introduction}

Seasonal change in tropical climate countries like Indonesia causes variations in soil moisture content. On expansive soil, this seasonal cycle influences the soil moisture content in the upper few meters, which is generally termed as the active zone. Soil water evaporation during the dry season decreases soil moisture content. In wet season, when it rains, water infiltration into the soil increases the water content. This water content variation induces changes in physical and mechanical characteristics of the soil, especially for expansive soil [1-5]. The change of water content due to seasonal cycles would cause shrinking and swelling in expansive soil. The differential movement caused by shrinkage or swell of expansive soils can increase the probability of damage to the foundation and superstructure.

In the case of pile foundation, the change of water content due to drying and wetting cycles leads to changes in the friction capacity of piles. In this research, a series laboratory experiments were conducted considering the water content variations and pile material to investigate the friction capacity of piles under drying and wetting cycle. 


\section{Literature Review}

The change in water content greatly affects the strength of expansive soils used in structural foundations. Expansive soils are bound together by electrochemical bonds between individual particles, as soil cohesion. Water content significantly modifies the soil cohesion. As water content increases, soil cohesion decreases. This is because increasing the water content can change the distance between particles, decreasing the strength of the inter-particle bonds. The decrease in bond strength results in a decrease in cohesion and a loss of shear strength.

In previous study, it was shown that soil cohesion in dry season reaches four times higher than in wet season. For example, in the dry season, cohesion was $149 \mathrm{kN} / \mathrm{m}^{2}$, while in wet season, cohesion decreased up to $37 \mathrm{kN} / \mathrm{m}^{2}[1,6]$.

In clayey soil, load capacity of pile was strongly determined by the friction between pile and soil. The friction capacity $\left(\mathrm{Q}_{\mathrm{f}}\right)$ was determined using the equation as shown in Eq. 1 [7].

$$
\mathrm{Q}_{\mathrm{f}}=\alpha \mathrm{c}_{\mathrm{u}} \mathrm{A}_{\mathrm{s}}
$$

Where $\alpha$ is adhesion factor, $c_{u}$ is undrained shear strength, and $A_{s}$ is the contact area between pile and soil.

There are several charts showing the relationship between undrained shear strength and adhesion factor, which were suggested by some researcher to determine adhesion factor. Some of them are shown in Figure 1 [8].

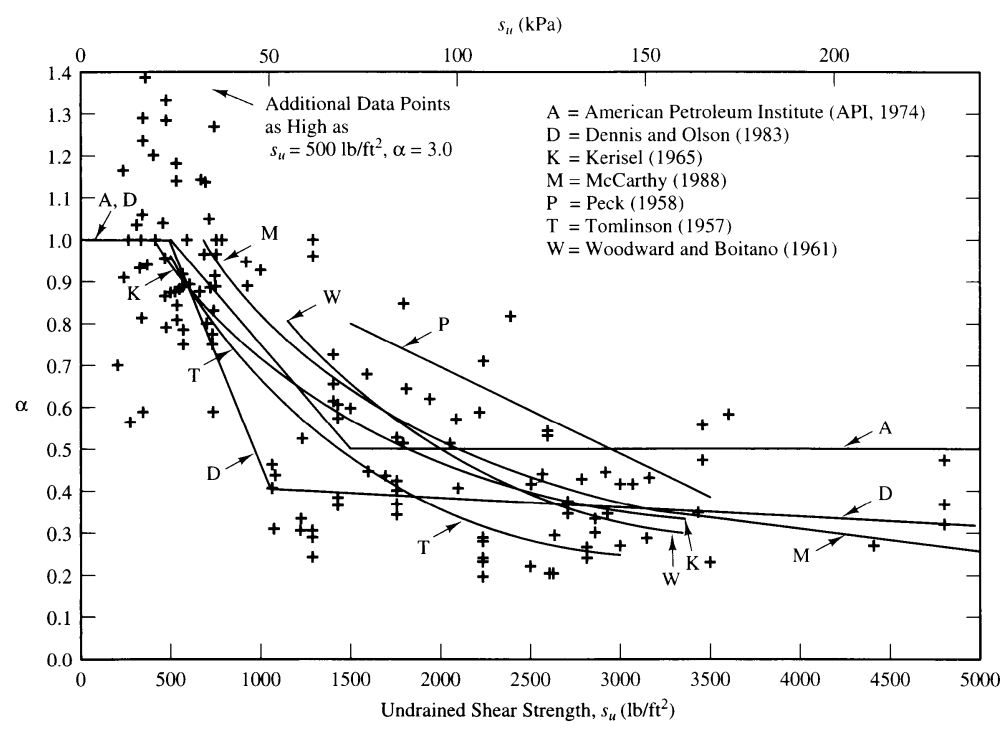

Figure 1. Adhesion Factor [8]

\section{Characteristics of Soil Sample}

In this research, field and laboratory experimental was conducted using soil sample taken from Citraland, West Surabaya, Indonesia. The initial characteristics of soil sample such as: water content, specific gravity, liquid limit, plastic limit, soil particle, and soil classification is shown in Table 1. 
Table 1. Initial Characteristics of Soil Sample

\begin{tabular}{|c|c|c|c|c|c|c|c|c|}
\hline \multirow{2}{*}{$\begin{array}{c}\text { Water } \\
\text { content } \\
(\%)\end{array}$} & \multirow{2}{*}{$\begin{array}{l}\text { Specific } \\
\text { gravity }\end{array}$} & \multirow{2}{*}{$\begin{array}{l}\text { Liquid } \\
\text { limit } \\
(\%)\end{array}$} & \multirow{2}{*}{$\begin{array}{c}\text { Plastic } \\
\text { limit } \\
(\%)\end{array}$} & \multicolumn{3}{|c|}{ Soil particles } & \multirow{2}{*}{$\begin{array}{l}\text { Undrained } \\
\text { shear } \\
\text { strength, } \mathrm{c}_{\mathrm{u}} \\
\left(\mathrm{kg} / \mathrm{cm}^{2}\right)\end{array}$} & \multirow{2}{*}{$\begin{array}{c}\text { Soil } \\
\text { classification } \\
\text { (USCS) }\end{array}$} \\
\hline & & & & $\begin{array}{c}\text { gravel } \\
(\%)\end{array}$ & $\begin{array}{c}\text { sand } \\
(\%)\end{array}$ & $\begin{array}{c}\text { fines } \\
(\%)\end{array}$ & & \\
\hline 44.5 & 2.65 & 109 & 30 & 0 & 0.11 & 99.9 & 0.26 & $\mathrm{CH}$ \\
\hline
\end{tabular}

\section{Research Methodology and Experimental Procedure}

The experimental research was conducted to investigate the friction capacity of piles under drying wetting cycles. The friction capacities of piles were determined by the field and laboratory tests. In the field, test pile model with a diameter of $5.7 \mathrm{~cm}$ and a length of $1 \mathrm{~m}$ was inserted to the soil. The schematic of the field test is presented in Figure 2. The first step, the model pile was inserted to the soil to investigate the total capacity of piles (Figure 2a). Afterward, pile covered with casing was inserted to the soil to investigate the end bearing load only (Figure $2 b$ ). Thus, the friction load of piles could be determined by subtracting its end bearing load from its total capacity. In the field, Cone Penetration Test (CPT) was also conducted to investigate the effect of pile material in friction capacity of piles. CPT piles could represent steel pile material, thus the friction capacity of steel pile could be determined. This field experiment was done to obtain the validity of laboratory experiment.

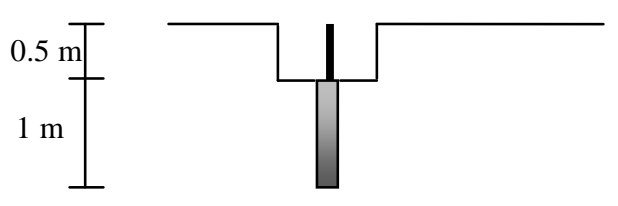

(a)
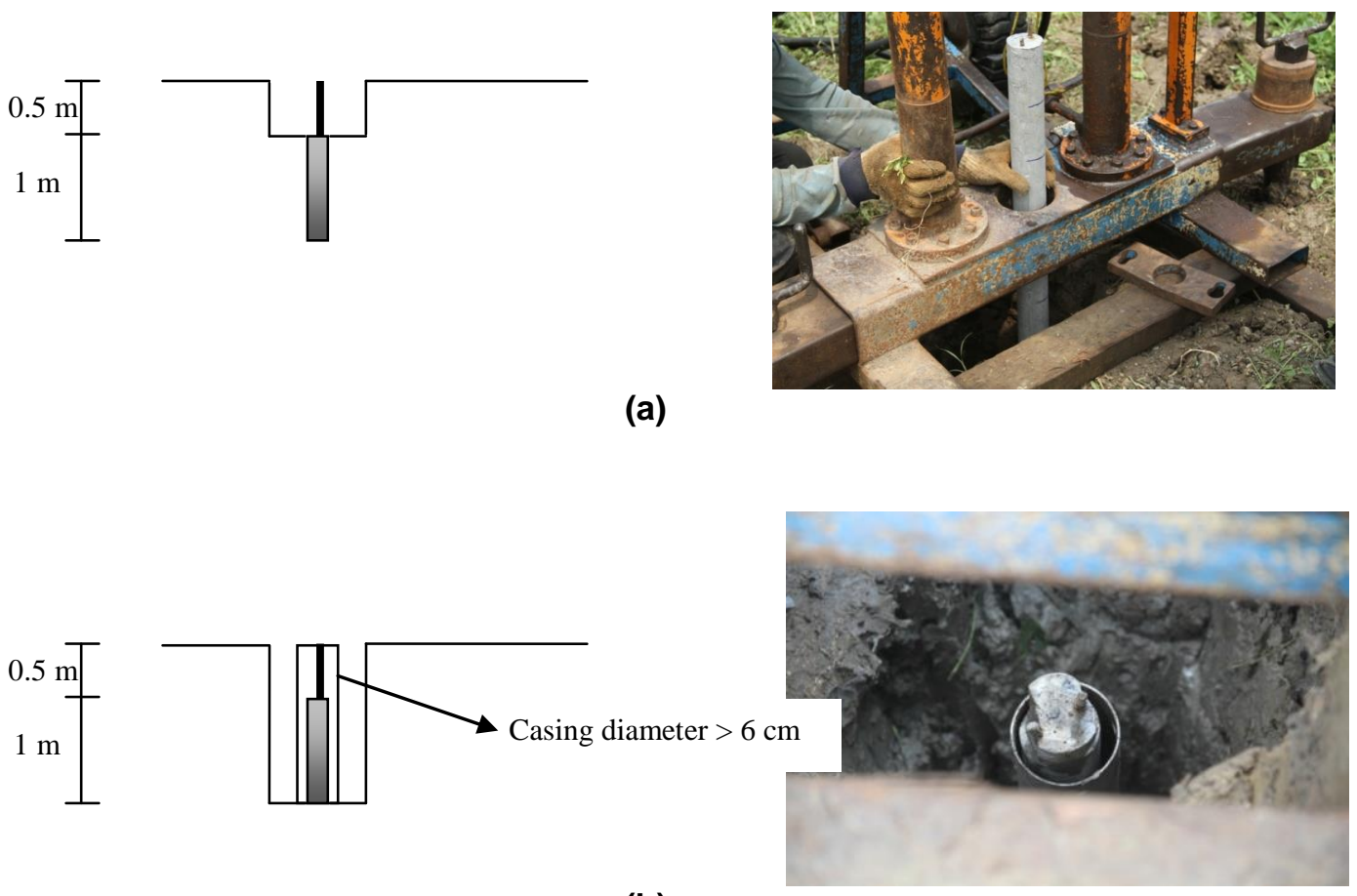

(b)

Figure 2. Field Experiment (a) Total Pile Load (b) End Bearing

Undisturbed soil sample was taken by pipe tube with a diameter of $15.24 \mathrm{~cm}(6$ ") and a length of $15 \mathrm{~cm}$ as shown in Figure 3. Soil sample was taken at a depth of $1 \mathrm{~m}$. 
The weight of undisturbed soil sample was also measured to ensure the uniformity of soil sample in all tubes. Afterward, undisturbed soil sample was wrapped in plastic to maintain its water content same as in its field condition.

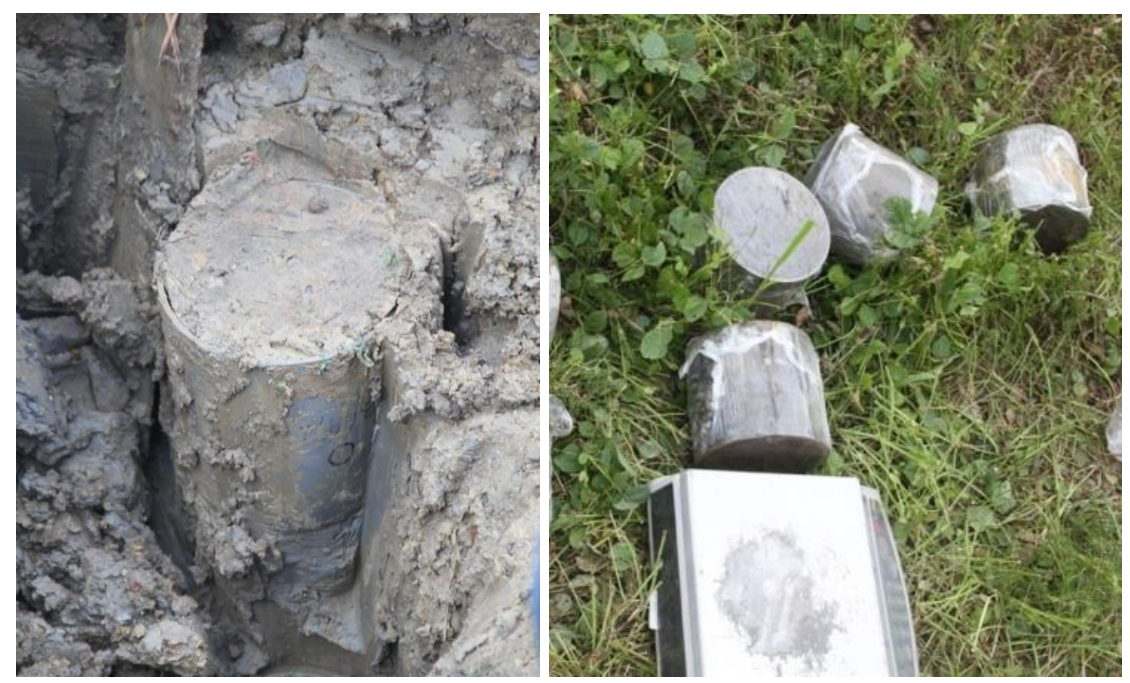

Figure 3. Soil Sampling

For laboratory experimental, concrete and steel model piles were made with a diameter of $1 \mathrm{~cm}$ and a length of $30 \mathrm{~cm}$. As shown in Figure 4, a test pile was inserted to the soil sample tube to investigate its friction capacity. The soil sample tube was made by PVC with $15.24 \mathrm{~cm}$ (6") in diameter considering the boundary effect of 15 times pile diameter [9-10].

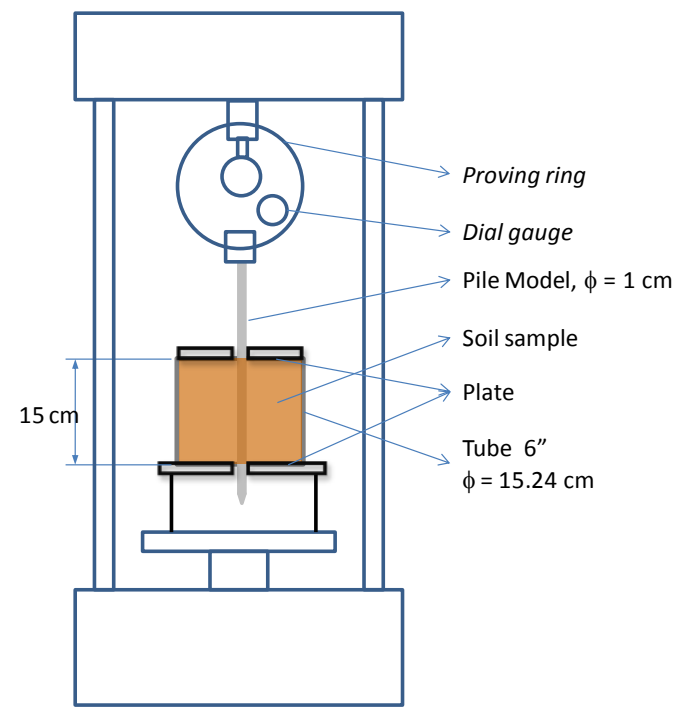

Figure 4. Laboratory Model Pile

The soil sample in the tube was tested considering water content variation based on the field condition. Based on the secondary data from Soil Test Company in Surabaya, the variation of soil moisture content at West Surabaya due to seasonal change 
throughout the year range from $25 \%$ to $55 \%$ (Figure 5 ). The water content variation in this research is showed in Table 2.

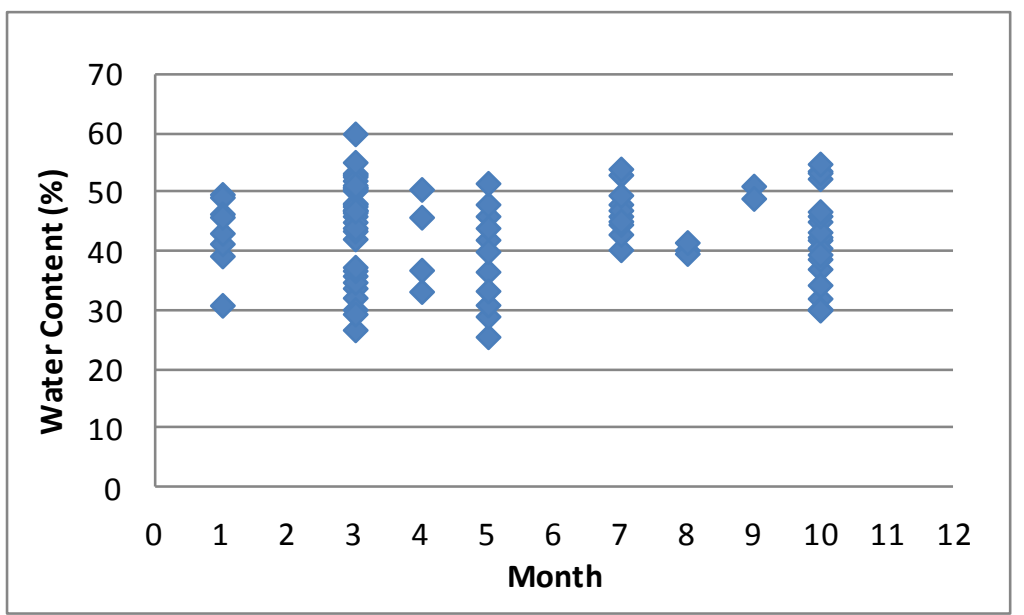

Figure 5. Variation of Water Content at West Surabaya in a Year

Table 2. Drying and Wetting Condition

\begin{tabular}{c|c|c|c|c|c|c|c|c|c}
\hline & $\begin{array}{c}\text { Wetting } \\
15 \%\end{array}$ & $\begin{array}{c}\text { Wetting } \\
10 \%\end{array}$ & $\begin{array}{c}\text { Wetting } \\
5 \%\end{array}$ & Initial & $\begin{array}{c}\text { Drying } \\
10 \%\end{array}$ & $\begin{array}{c}\text { Drying } \\
20 \%\end{array}$ & $\begin{array}{c}\text { Drying } \\
30 \%\end{array}$ & $\begin{array}{c}\text { Drying } \\
40 \%\end{array}$ & $\begin{array}{c}\text { Drying } \\
50 \%\end{array}$ \\
\hline \hline $\begin{array}{c}\text { Water } \\
\text { Content } \\
(\%)\end{array}$ & 51.18 & 48.95 & 46.73 & 44.5 & 40.05 & 35.06 & 31.15 & 26.7 & 22.25 \\
\hline $\begin{array}{l}\text { Note: Drying } \mathrm{x} \% \rightarrow \mathrm{w}_{\mathrm{c}(\mathrm{x})}=\mathrm{w}_{\mathrm{c} \text { (initial) }}-\mathrm{x} \% \mathrm{w}_{\mathrm{c} \text { (initial) }} \\
\text { Wetting } \mathrm{y} \% \rightarrow \mathrm{w}_{\mathrm{c}(\mathrm{y})}=\mathrm{w}_{\mathrm{c} \text { (initial) }}+\mathrm{y} \% \mathrm{w}_{\mathrm{c} \text { (initial) }}\end{array}$
\end{tabular}

\section{Result and Discussion}

The results of this research were obtained by doing several field and laboratory experiments. Laboratory loading test was conducted to represent the loading test at the field. Friction capacity of concrete piles at the laboratory and field were $0.154 \mathrm{~kg} / \mathrm{cm}^{2}$ and $0.192 \mathrm{~kg} / \mathrm{cm}^{2}$, respectively. Friction capacity of steel piles at the laboratory and field is $0.245 \mathrm{~kg} / \mathrm{cm}^{2}$ and $0.267 \mathrm{~kg} / \mathrm{cm}^{2}$, respectively. It can be concluded that the accuracy of concrete and steel model pile is $80 \%$ and $92 \%$, respectively.

\subsection{Drying - Wetting}

The relationship between friction load and displacement of model piles is shown in Figure 6 and Figure 7. In general, frictions load increased with the decreasing water content. Drying and wetting cycles greatly affected the friction capacity of piles. The difference of friction capacity in the range between wetting $15 \%$ to drying $50 \%$ was 8.7 times for concrete pile and 9.3 times for steel pile. At more dry condition, when soil becomes unsaturated, suction phenomena might be occurred. Soil suck any material within, hence the increasing of friction load. On steel pile model (Figure 7), the friction load continued to increase with the increasing displacement until it reaches its peak point and then decreased. While on concrete model pile, the increasing of friction load is not as steep as on a steel model pile and it has no peak point (Figure 6). 


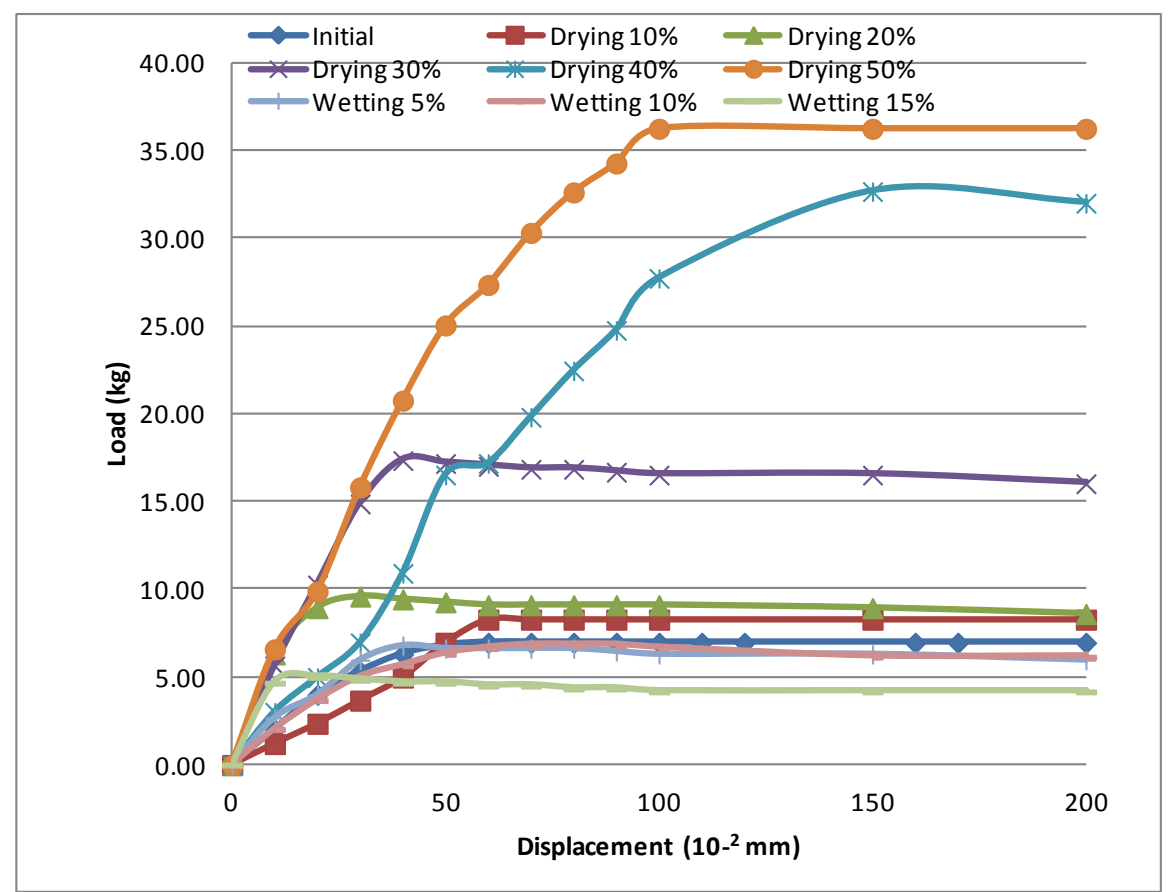

Figure 6. Load - Displacement Curve of Concrete Pile Model

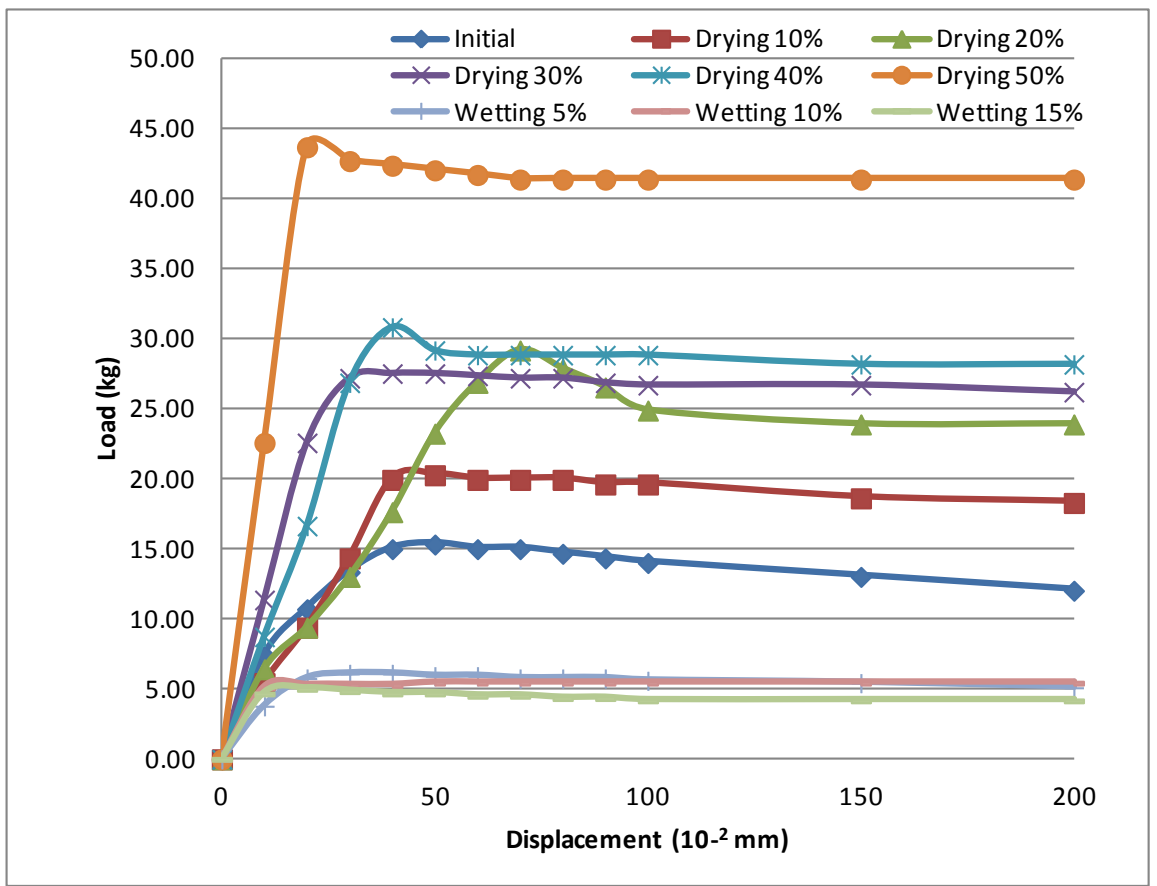

Figure 7. Load - Displacement Curve of Steel Pile Model

\subsection{Pile Material}

From these tests, it could be concluded that when pile inserted to the expansive soil, the steel pile has higher friction capacity compare with the concrete pile, especially at drying $20 \%$ condition (Table 3 and Figure 8). This phenomenon is thought that suction 
between soil and steel material stronger than suction between soil and concrete material. It might happen because the surface of concrete more porous than steel material, hence soil suck steel material stronger than concrete material.

At initial condition up to drying $30 \%$, the difference between steel and concrete piles friction load is considerably high. The friction load differences increased with the increasing drying condition until drying 30\% was reached. However, as drying condition reached up to drying $40 \%$ and $50 \%$, the friction load differences between steel and concrete pile getting smaller. Likewise, as water content increased, from wetting $5 \%$ up to wetting $15 \%$, friction load of steel and concrete piles were almost the same.

Table 3. Friction Load Differences between Concrete and Steel Pile

\begin{tabular}{|l|r|r|r|}
\hline \multicolumn{1}{|c|}{ Condition } & $\begin{array}{c}\text { Friction Load for } \\
\text { Concrete } \mathbf{( k g )}\end{array}$ & $\begin{array}{c}\text { Friction Load for } \\
\text { Steel (kg) }\end{array}$ & \multicolumn{2}{|c|}{$\begin{array}{c}\text { Difference } \\
\text { (kg) }\end{array}$} \\
\hline Initial & 6.98 & 12.04 & 10.07 \\
\hline Drying 10\% & 8.30 & 18.31 & 15.30 \\
\hline Drying 20\% & 8.62 & 23.92 & 10.18 \\
\hline Drying 30\% & 16.05 & 26.23 & 3.84 \\
\hline Drying 40\% & 32.05 & 28.21 & 5.11 \\
\hline Drying 50\% & 36.30 & 41.41 & 0.87 \\
\hline Wetting 5\% & 5.98 & 5.11 & 0.71 \\
\hline Wetting 10\% & 6.15 & 5.44 & 0.28 \\
\hline Wetting 15\% & 4.17 & 4.45 & \\
\hline
\end{tabular}

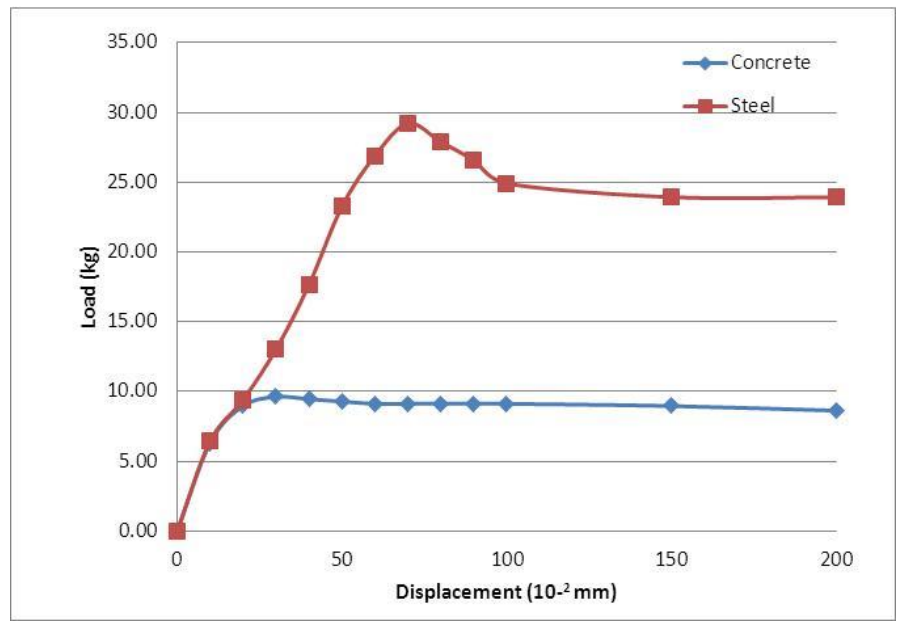

Figure 8. Load - Displacement Curve of Pile Model at Drying $20 \%$

\section{Concluding Remarks}

A series of experiments were conducted to investigate the effect of water content variation and pile material on friction capacity. The following is a summary of the conclusion from this investigation:

1. The laboratory loading test could represent the field loading test, it has a $80 \%$ accuracy rate for concrete pile and $92 \%$ for steel pile. 
2. Drying and wetting greatly affected the friction capacity of pile foundation. Friction load increased with the decreasing water content. The difference of friction capacity in the range between wetting $15 \%$ to drying $50 \%$ was about eight to nine times.

3. In steel pile model, the friction load continued to increase with the increasing displacement until it reaches its peak point and then decreased. While on concrete model pile, the increasing of friction load is not as steep as on a steel model pile and it has no peak point.

4. On expansive soil, steel pile has higher friction capacity compare with concrete piles. However, in wetting condition and very dry condition (drying $40 \%$ and 50 $\%)$, friction load of steel and concrete piles were almost the same.

Furthermore, another type of clay, for example non-expansive soil is necessary to be observed so this research could represent the problem at the field more widely. The behavior of friction capacity changes might be different for non-expansive soil.

\section{Acknowledgements}

This study is supported by the Department of Civil Engineering, Sepuluh Nopember Institute of Technology (ITS), Surabaya, Indonesia and the Department of Civil Engineering, Petra Christian University, Surabaya, Indonesia. The authors greatly acknowledge for all the support received.

\section{References}

[1] Y., "A Geotechnical Study on the Landslides in the Trabzon Province", NE, Turkey. Applied Clay Science, vol. 52, (2011), pp. 11-19.

[2] I., "Drying and Wetting Cyclus against Foundation Failure", Proceedings of HATTI Seminar, Bandung. Indonesia, (2008).

[3] M. Muntaha, R. A. Soemitro, N. Endah and I., "Charachteristics of Tropical Residual Soils in Arjasa Jember of East Java”, International Journal Academic Research, vol. 2, no. 5, (2010).

[4] S. W. C. Au, "Rain-Induced Slope Stability in Hong Kong", Engineering Geology, vol. 51, (1998), pp. 1-36.

[5] S. Badawi and I., "Behaviour of Expansive Undisturbed Soil and Remoulded Soil under Drying and Wetting Cycle", National Seminar VI 2010 Civil Engineering ITS, Surabaya. Indonesia, (2010).

[6] N. A. Shayea, "The Combined Effect of Clay and Moisture Content on the Behavior of Remolded unsaturated Soils", Engineering Geology, vol. 62, (2001), pp. 319-342.

[7] M. J. Tomlinson, "Foundation Design and Construction", Prentice Hall, (2001).

[8] D. P. Coduto, "Foundation Design Principles and Practices", Prentice-Hall, Inc, New Jersey, (2001).

[9] A. I. Mhaidib, "Effect of Rate of Loading on Uplift Capacity of a Model Pile in Clay", Proceedings of the Eleventh (2001) International Offshore and Polar Engineering Conference, Stavanger, Norway, (2001).

[10] H. G. Poulos, "Effect of Pile Driving on Adjacent piles in Clay", Canadian Geotechnical Journal, vol. 31, (1994), pp. 856-867.

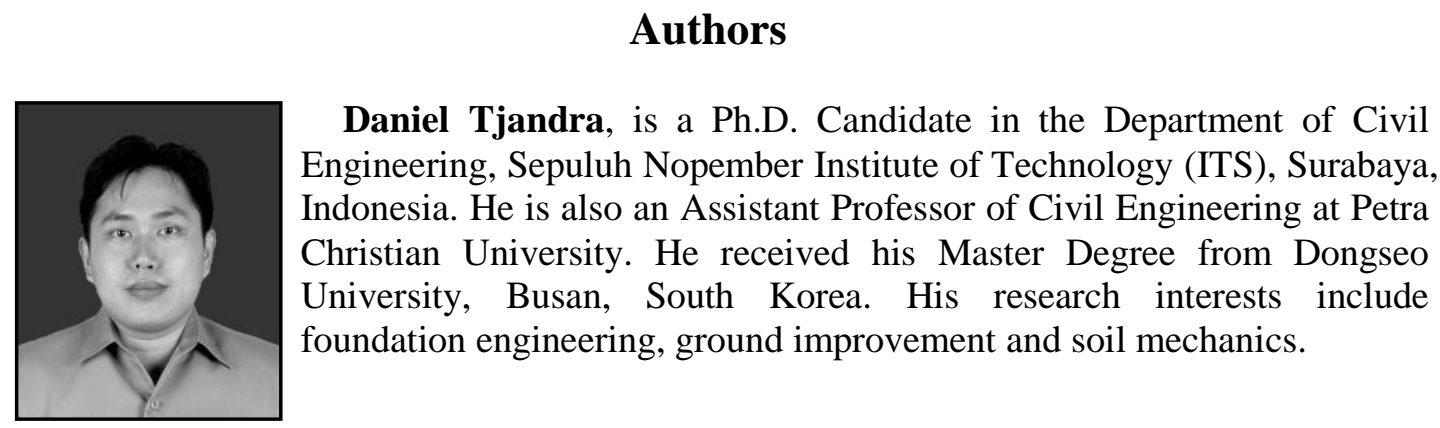




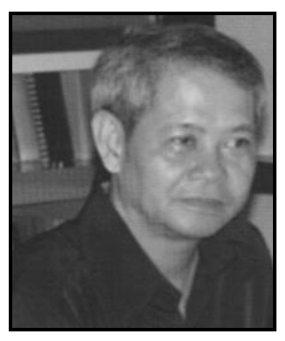

Indarto, is a Professor of Civil Engineering at ITS. He received his Ph.D. from Ecole Centrale Paris, France. He is a Regional Head of Indonesian Society of Geotechnical Engineer. His research interests include expansive soil, foundation engineering and ground improvement.

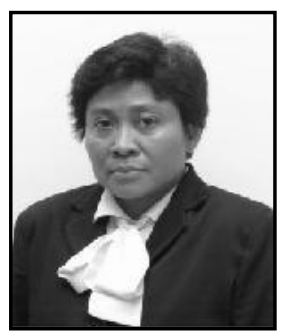

Ria Asih Aryani Soemitro, a Associate Professor of Civil Engineering at ITS. She received her Ph.D. in Geotechnical Engineering from Ecole Centrale Paris, France. Her research interests include soil characteristic, foundation engineering and slope stability. 